\title{
Kautilya's Arthashastra: A Recognizable Source of the Wealth of Nations
}

\author{
Balbir S. Sihag \\ University of Massachusetts Lowell, Lowell, USA \\ Email: balbir_sihag@uml.edu
}

Received 7 January 2016; accepted 1 February 2016; published 4 February 2016

Copyright (C) 2016 by author and Scientific Research Publishing Inc.

This work is licensed under the Creative Commons Attribution International License (CC BY). http://creativecommons.org/licenses/by/4.0/

(c) (7) Open Access

\section{Abstract}

It is almost a unanimously accepted view that The Wealth of Nations does not contain a single original idea establishing the fact that Adam Smith borrowed all key ideas from various sources. He believed that he could claim originality for all the important ideas if he concealed their sources. Ferguson exposed Adam Smith for making a false claim related to the pin-factory example. It is intended to continue the process initiated by Ferguson by identifying paragraphs on sources of economic growth, canons of taxation and undesirability of monopolies, the core of The Wealth of $\mathrm{Na}$ tions, which are textually quite similar to those in The Arthashastra. It is claimed that Adam Smith lifted those ideas from The Arthashastra. It is indicated in the Appendix that more than two hundred years before Adam Smith, Machiavelli also seems to have access to The Arthashastra. Hopefully this process continues until all of Adam Smith's sources are identified and duly acknowledged.

\section{Keywords}

Division of Labor, Economic Growth, Canons of Taxation, Monopoly, Monopsony, Transmission, Delegation

\section{Introduction}

It is truly astounding that there is almost a consensus that Adam Smith's The Wealth of Nations does not contain anything that may qualify as original. Adam Smith merely collected materials from various sources. Often he expressed the borrowed material in his own language and also tried to synthesize it although with some inconsistencies. ${ }^{1}$ Sometimes, he acknowledged his sources, and other times the honorable Dr. concealed them, as-

${ }^{1}$ [11] Barber (1967, p. 51) observes, "Little of the content of The Wealth of Nations can be regarded as original to Smith himself. Most of the book's arguments had in one form or another been in circulation for some time."

Barber (1967, p. 51) notes, "Smith’s talents as a synthesizer, however, were the source of some analytical imperfections in his writing. At a number of points he offered explanations that were ambiguous or inconsistent." Similarly, the remarks by [12] Grampp about Adam Smith that "to make the ideas of Smith consistent, an honor he was not sure he merited" are quite indicative. 
suming, perhaps that no one would bother to find that out. That proved to be an unrealistic assumption, particularly when the source was too obvious to be concealed. As an illustration, in emphasizing the importance of division of labor, he used the example of the pin-factory, although he did not acknowledge its source but reproduced it as he had found it in the French Encyclopédie (1755). ${ }^{2}$

Adam Smith borrowed key ideas both from western and non-western sources, but avoided acknowledging them. ${ }^{3}$ If his borrowed feathers were returned to the owners, the unearned title of "father of economics" would also fly away with the feathers. Adam Smith personally supervised the burning of his confidential papers to destroy not just his incomplete manuscripts but also evidence related to his sources. Nevertheless, at least in three areas, Adam Smith's debt to Kautilya is clearly recognizable: 1) identification of land, labor and capital as the sources of economic growth; 2) the four canons of taxation: a) certainty of tax liability, b) tax liability in proportion to benefit (income), c) economy in collection and d) convenience to the tax payer in making payment; and 3) undesirability of monopolies. Section 3 presents paragraphs related to the sources of growth from Kautilya's Arthashastra and from Adam Smith's The Wealth of Nations. Paragraphs related to the four canons of taxation are presented in Section 4. Kautilya's and Adam Smith's views on the undesirability of monopolies are presented in Section 5. Final section contains some concluding observations. Section 2 briefly presents the respective scopes of The Arthashastra and The Wealth of Nations.

\section{Kautilya and Adam Smith on the Scope of Economics}

Scope of The Arthashastra: Interestingly, rather than stating the scope of his Arthashastra in the beginning, [1] Kautilya (p. 100) makes the following claim at the end: "By following [the principles set out in] this treatise one can not only create and preserve dharma [spiritual good], artha [material well-being] and kama [aesthetic pleasures] but also destroy [their opposites, i.e.,] unrighteousness, material loss and hatred. It is a guide not only for the acquisition of this world but also the next (15.1)."

Two things are obvious: first, Kautilya put strengthening and promotion of dharma (ethics) ahead of artha (material well-being) since he believed dharma not only paved the way to bliss but also to prosperity. Secondly, he considered his Arthashastra as a manual on engineering Yogakshema-peaceful enjoyment of prosperity-for all the people. The concept of Yogakshema is much broader and holistic than the currently used concept of human security. Capitalism was emerging and both urbanization and monetization were increasing at the time. ${ }^{4}$ Keeping those trends in view, Kautilya proposed a judicious mix of visible and invisible hands.

He understood the allocative role of prices. ${ }^{5}$ He suggested incentives to promote economic growth in the private sector. At that time, Kings used to spend most of the tax revenue on building luxurious palaces and very little on building infrastructure. However, Kautilya (p. 149) suggested, "Hence the king shall be ever active in the management of the economy. The root of wealth is economic activity and lack of it brings material distress. In the absence of fruitful economic activity, both current prosperity and future growth are in danger of destruction. A king can achieve the desired objectives and abundance of riches by undertaking productive economic activity

${ }^{2}[13]$ Murray Rothbard (1995, Chap. 16) points out, "When Smith upbraided Ferguson for not acknowledging Smith’s precedence in the pinfactory example, Ferguson replied that he had borrowed nothing from Smith, but indeed that both had taken the example from a French source "where Smith had been before him". There is strong evidence that the "French source" for both writers was the article on Epingles (pins) in the Encyclopédie (1755), since that article mentions 18 distinct operations in making a pin, the same number repeated by Smith in the Wealth of Nations, although in English pin factories 25 was the more common number of operations." He concluded, "The problem is not simply that Smith was not the founder of economics. The problem is that he originated nothing that was true, and that whatever he originated was wrong."

${ }^{3}$ It appears that the tradition of concealing sources, perhaps started with Fibonacci (1202). [14] Charles Burnett (2005) observes, "By the end of the twelfth century the "algorismus" was widespread and it would certainly have been known to Fibonacci. In fact he refers specifically to the "algorismus", in the preface to his Liber abbaci, as we have seen. But it is difficult to see why he should criticise it alongside the "Gerbertian abacus", and state that the "method of the Indians" is better, when the "algorismus" is precisely "the method of the Indians". I suspect that his reason is that he thinks that, or wants to give the impression that, his own work is truly innovatory, for he scrupulously avoids mentioning the name of al-Khwarizmi. (In chapter 15 he uses only al-Khwarizmi’s first name (ism), "Maumeht”). Are we to suppose that Fibonacci was, in fact, ignorant of this Latin tradition of Indian arithmetic, and re-introduced the place-value numerals afresh from the Arabs?”

${ }^{4}[15]$ Drekmeier (1962, p. 105) describes, "The Ganges valley in the seventh century was the home of a nascent capitalism as well."

${ }^{5}$ According to Spengler (1971), Kautilya understood the role of prices. Spengler (p. 74) states, "Prices reflected actual or potential scarcity (4.2; 2.21.7-14) as well as the presence of monopolistic arrangements (2.6.10; 4.2.18-19, 28-30)."

He (1971, p. 74) explains: "His analysis, of course, was implicit, not explicit; it rested upon the assumption that individual behavior could be controlled in large measure through economic rewards and penalties, particularly when these were commensurate with the action to be encouraged or discouraged."

He (1971, p. 158) concludes: "Kautilya was, of course, familiar with the general nature of man's response to changes in price and income as well as to changes in the structure of rewards and penalties." 
(1.19).” He suggested to build roads, water works, "remove all obstructions to economic activity” and create an ethical environment. He identified a) capital, labor and land as the sources of economic growth, b) suggested incentives to encourage supplies of these inputs, c) devised a tax system, that included not only the principles of taxation and a piecewise linear income tax but also measures for compliance and d) formulated laws that promoted economic efficiency and ethical fabric of the society. He believed that ruler's ethical conduct, and not institutions, was the "deep determinant" of economic growth. According to him, a king should be a rajarishi, ethical and wise like a sage and create an ethical environment.

Until recently, Kautilya has been the only economist who suggested both preventive and remedial measures to handle systemic risk. He (p. 116) stated, "In the interests of the prosperity of the country, a king should be diligent in foreseeing the possibility of calamities, try to avert them before they arise, overcome those which happen, remove all obstructions to economic activity and prevent loss of revenue to the state (8.4).” He identified threat of an aggression, occurrence of a famine and moral decay as sources of systemic risk. ${ }^{6}$

Scope of The Wealth of Nations: [2] Adam Smith (Book 1, p. 394) wrote, "But the great object of the political economy of every country, is to increase the riches and power of that country." One would expect that The Wealth of Nations would cover how a nation should enhance its power and enrich its people. As [3] Prasch (1991) comments, "First, the title of the book, An Inquiry into the Nature and Causes of The Wealth of Nations, as well as his lengthy tracts about the mercantilists' confusion with regard to the formation of wealth, lends credence to the view that he shared the mercantilists' goals, namely the development of England's wealth and power as a policy goal. Reviewing book 4 of The Wealth of Nations, one finds that Smith never raises issue with the mercantilists' policy goals, only with their attempts to achieve them.” However, Adam Smith's discussion on national security was inadequate. He followed Machiavelli, who did not have much to say on national security (See [4] Sihag (2016)).

Then, in Book IV, Adam Smith (Book IV, p. 449) defines, "Political economy, considered as a branch of the science of a statesman or legislator, proposes two distinct objects: first, to provide a plentiful revenue or subsistence for the people, or more properly to enable them to provide such a revenue or subsistence for themselves; secondly, to supply the state or commonwealth with a revenue sufficient for the public services. It proposes to enrich both the people and the sovereign." One would expect that he would explain, at the minimum, how to bring prosperity. As [5] Dorfman (1991) notes, "Wealth of Nations was primarily a treatise on economic development." However, Adam Smith borrowed only the sources of economic growth from The Arthashastra and ignored how to engineer prosperity. Thus, the scope of The Wealth of Nations is very limited. On the other hand, Kautilya's Arthashastra is comprehensive, consistent, concise, coherent and rigorous. ${ }^{7}$ The following table may capture the relative scopes of The Arthashastra and The Wealth of Nations (Table 1).

Adam Smith's invisible hand would be confined only to Case 1 where there is no conflict between the public interest and the private interest. Whereas, Kautilya suggested steps to manage all the cases. Incidentally, both Confucius and Kautilya paid special attention to Case IV. If Adam Smith had borrowed all of Kautilya's insights or not concealed the sources, other researchers could have benefitted significantly.

\section{Kautilya and Adam Smith on Economic Growth}

As mentioned above, Kautilya had identified Land, Labor and Capital as the sources of economic growth. Assembly-type division of labor, what is now called Fordism, was practiced during fourth century BCE in India

\footnotetext{
${ }^{6}$ Adam Smith considered "justice is the pillar on which the whole edifice rests" but no discussion, on how to build the pillar and its base, was provided. Moreover, he never examined how the rules of justice were formulated, interpreted or implemented. [16] He ((1790/1982, p. 175) asserted, "The rules of justice may be compared to the rules of grammar; the rules of the other virtues, to the rules which critics lay down for the attainment of what is sublime and elegant in composition.” The concept of justice itself is ambiguous and its rules are formulated by less than perfect individuals, implying an unavoidable imprecision. Thus, rules of justice could not be like grammar. If they were, would there be any kangaroo courts? Would there be "black" and "white” justice? If they were like grammar, would there be need for any lawyers? Thus, it is an inappropriate comparison. He did not understand justice.

${ }^{7}$ Sihag (2014) presents Kautilya's in-depth analysis of the following: The Arthashastra consists of three reasonably developed but interrelated parts. (a) Economic Issues: This part deals with Principles and policies related to economic growth, taxation, international trade, efficient, clean and caring governance, moral and material incentives to elicit effort and preventive and remedial measures to deal with famines and other calamities and Accounting Methods. (b) Law and Economics: Kautilya devotes the second part to administration of justice, minimization of legal errors, formulation of ethical and efficient laws, labour theory of property, regulation of monopolies and monopsonies, protection of privacy, laws against sexual harassment and child labour. (c) Application of economic analysis to National Security: This part discusses all aspects of national security, such as energetic, enthusiastic, well trained and equipped soldiers, most qualified and loyal advisers, strong public support, setting-up an intelligence and analysis wing, negotiating a favourable treaty, military tactics and strategy, and diet of soldiers to enhance their endurance are covered.
} 
and Kautilya did not see the need to mention it. ${ }^{8}$ The following Table 2 presents their identification of the sources of economic growth.

Kautilya in emphasizing the contribution of capital wrote "Man, without wealth, does not get it even after a hundred attempts". Adam Smith expressed that as machines "facilitate and abridge labor, and enable one man to

Table 1. Kautilya and Adam smith on public and private interests.

\begin{tabular}{lll}
\hline & \multicolumn{1}{c}{ Public interest } & \multicolumn{1}{c}{ Against public interest } \\
\hline $\begin{array}{l}\text { Private } \\
\text { interest }\end{array}$ & $\begin{array}{l}\text { Ideal } \\
\text { Case I }\end{array}$ & $\begin{array}{l}\text { In private interest but against public interest (conflicts of interest): } \\
\text { monopoly, lobbying, financial manipulation, insider trading, } \\
\text { regulatory arbitrage, free riding etc. } \\
\text { Case III }\end{array}$ \\
$\begin{array}{l}\text { Against } \\
\text { private } \\
\text { interest }\end{array}$ & $\begin{array}{l}\text { In public interest but against private interest } \\
\text { (conflicts of interest): charitable activities, serving } \\
\text { the country etc. } \\
\text { Case II }\end{array}$ & $\begin{array}{l}\text { Against both public and private interests (worst): actions motivated } \\
\text { by the destructive vices, such as excessive greed, anger, lust, } \\
\text { jealousy etc. } \\
\text { Case IV }\end{array}$ \\
\hline
\end{tabular}

Table 2. Sources of economic growth.

\begin{tabular}{|c|c|c|}
\hline $\begin{array}{c}\text { Sources of } \\
\text { economic } \\
\text { growth }\end{array}$ & Kautilya & Adam Smith \\
\hline $\begin{array}{l}\text { Importance } \\
\text { of capital }\end{array}$ & $\begin{array}{l}\text { "Man, without wealth, does not get it even after a hundred } \\
\text { attempts. Just as elephants are needed to catch elephants, so } \\
\text { does wealth capture more wealth, Wealth will slip away from } \\
\text { that childish man who constantly consults the stars. The only } \\
\text { [guiding] star of wealth is itself; what can the stars of the sky } \\
\text { do? (9.4.26-27)." } \\
\text { Kautilya (p. 664) observed, "On the other hand, one fighting } \\
\text { with a tiny army perishes like one trying to cross the ocean } \\
\text { without a boat (12.1)." }\end{array}$ & $\begin{array}{l}\text { He (p. 11) states that machines "facilitate and abridge } \\
\text { labor, and enable one man to do the work of many.” } \\
\text { Adam Smith (p. 13, ft. 1): [Examples are given in } \\
\text { Lectures, p. 167: “Two men and three horses will do } \\
\text { more in a day with the plough than twenty men } \\
\text { without it. The miller and his servant will do more } \\
\text { with the water mill than a dozen with the hand mill, } \\
\text { though it too be a machine.”] }\end{array}$ \\
\hline $\begin{array}{l}\text { Importance } \\
\text { of labor }\end{array}$ & $\begin{array}{l}\text { He (p. 619) stated, “The value of land is what man makes of it } \\
\text { (7.11).” } \\
\text { He (p. 621) added, "A king who trusts in fate and does not } \\
\text { believe in human effort will fail because such a king never } \\
\text { begins a work and never achieves anything (7.11).” } \\
\text { He (p. 685) stated, "It is better to have either an army } \\
\text { composed of Kshatriyas trained in the use of weapons or a } \\
\text { Vaishya or Sudra army with a large number of men (9.2).” }\end{array}$ & $\begin{array}{l}\text { p. 351: "There is one sort of labor which adds to the } \\
\text { value of the subject upon which it is bestowed: there is } \\
\text { another which has no effect. The former, as it } \\
\text { produces a value, may be called productive; the latter, } \\
\text { unproductive." }\end{array}$ \\
\hline $\begin{array}{l}\text { Importance } \\
\text { of land }\end{array}$ & $\begin{array}{l}\text { Kautilya (p. 617) stated, “Among the signatories to a treaty for } \\
\text { a joint campaign, he who acquires land [whether settled land } \\
\text { or virgin land] with [the maximum number of] ideal qualities } \\
\text { and with many developed productive facilities outman oeuvres } \\
\text { the others (7.10).” }\end{array}$ & $\begin{array}{l}\text { He (p. 195) states, "The acquisition of new territory, } \\
\text { or of new branches of trade, may sometimes raise the } \\
\text { profits of stock, and with them the interest of money, } \\
\text { even in a country which is fast advancing in the } \\
\text { acquisition of riches.” }\end{array}$ \\
\hline $\begin{array}{l}\text { Role of } \\
\text { institutions }\end{array}$ & $\begin{array}{l}\text { Kautilya (p. 108) observed, "By maintaining order, the king } \\
\text { can preserve what he already has, acquire new possessions, } \\
\text { augment his wealth and power, and share the benefits of } \\
\text { improvement with those worthy of such gifts. The progress of } \\
\text { this world depends on the maintenance of order and the } \\
\text { [proper functioning of] government (1.4).” }\end{array}$ & $\begin{array}{l}\text { (Bk. V, Ch. III, p. 445) "Commerce and manufactures } \\
\text { can seldom flourish long in any state which does not } \\
\text { enjoy a regular administration of justice, in which } \\
\text { people do not feel themselves secure in the possession } \\
\text { of their property, in which the faith of contracts is not } \\
\text { supported, and in which the authority of the state is } \\
\text { not supposed to be regularly employed in enforcing } \\
\text { the payment of debts from all those who are able to } \\
\text { pay.” }\end{array}$ \\
\hline
\end{tabular}

${ }^{8}$ [17] Basham (1959, p. 216) notes, "Though the basis of ancient Indian industry was at all times the individual craftsman, aided chiefly by members of his own family, larger manufactories, worked chiefly by hired labour, were by no means unknown." Further, "We read here and there of private producers who had far transcended the status of the small home craftsman, and who manufactured on a large scale for a wide market. Thus an early Jain a text tells of a wealthy potter named Saddalaputta who owned 500 potters' workshops, and a fleet of boats which distributed his wares throughout the Ganges valley; there are a few other references, which confirm that large scale production for a wide market was not unknown in ancient India.” Basham points out that the existence of co-operatives of workmen were also common. He asserts "Their existence tended to encourage division of labour; thus one man would fashion the shaft of an arrow, a second would fix the flights, and a third would make and fix the point.” 
do the work of many". There is hardly any difference since Adam Smith substituted "hundred" by "many". However, according to Kautilya, all workers contributed to income, whereas Adam Smith did not think so. We may summarize as follows:

1) Kautilya emphasized the importance of capital to economic growth so did Adam Smith. Both used simple examples to make the point. Industrial revolution was taking hold all around Adam Smith still he used simple examples. It indicates that he spent twelve years in collecting ideas from existing sources rather than shifting the knowledge frontier outwards.

2) Kautilya believed that capital and labor were complements so did Adam Smith.

3) Kautilya believed that use of capital increased labor productivity and saved labor and Adam Smith also believed that. They did not make any distinction between labor-augmenting and labor-saving.

4) Interestingly, Kautilya understood that training was labour-augmenting.

\section{Kautilya and Adam Smith on Principles of Taxation}

Kautilya emphasized certainty of taxation, proportional income tax, convenience of payment and economy in the collection of taxes. Additionally, Kautilya was concerned about tax evasion. He equated tax evasion to a theft and recommended strict enforcement. Adam Smith appreciated the tax system in India and other countries. He (1776, part II, p. 364) wrote, "The sovereigns of China, those of Bengal while under the Mahometan government, and those of ancient Egypt, are said accordingly to have been extremely attentive to the making and maintaining of good roads and navigable canals, in order to increase, as much as possible, both the quantity and value of every part of the produce of the land, by procuring to every part of it the most extensive market which their own dominions could afford.” The tax system in Bengal and others parts of India was the one recommended by Kautilya. ${ }^{9}$ It is no surprise, Adam Smith recommended the same canons of taxation. The following Table 3 presents their views on taxation.

Incidentally, Spengler brings out Kautilya's additional insights on taxation. [6] He (1971, p. 72) observes, "Kautilya's discussion of taxation and expenditure, apparently in keeping with traditional doctrine, gave expression to three Indian principles: taxation power is limited; taxation should not be felt to be heavy or excessive; tax increases should be graduated. One of his main concerns seems to have been the collection and expenditure of revenue in such ways as to build up the permanent revenue-yielding capacity of the economy. While he manifested little knowledge of tax shifting and incidence, he emphasized the long run, cautioned against too heavy taxation in the short run, and noted that a ruler could not tax at his pleasure, particularly in frontier regions whence disgruntled taxpayers could flee to neighboring countries.” (See [7] Sihag (2014, Chapter 12) for an in-depth analysis of Kautilya's ideas on taxation).

\section{Kautilya and Adam Smith on Undesirability of Monopoly}

Kautilya had suggested provision of public goods and regulation of externalities, monopolies and monopsonies by the government. Adam Smith suggested provision of public goods by the government but did not suggest any regulation of externalities and monopolies. However, neither Kautilya nor Adam Smith called them market failures. The following Table 4 presents their view on the undesirability of monopolies.

Kautilya did not use deadweight loss as the argument for the undesirability of monopolies. Instead he had argued that monopoly was undesirable since it oppressed people. Adam Smith also did not argue that monopoly was undesirable because it created a deadweight loss. He, just like Kautilya, argued that monopoly was undesirable because it oppressed people. This is indisputable evidence that Adam Smith had access to Kautilya's ideas. Interestingly, Kautilya equated charging of high prices through the formation of cartels to theft.

\footnotetext{
${ }^{9}$ John M. Keynes worked in the India Office and the following suggestion by Keynes was borrowed from the program initiated by Nawab Asaf-ud-Daula since there had been no such program in the whole world. Nawab Asaf-ud-Daula started a food for work program to help the famine-stricken people of Lucknow around 1784. Some workers were employed during daytime to construct a building known as Imambara. Others were hired at night to demolish part of what was constructed during the day time. The objective was to provide employment to as many workers as possible and as long as it was needed.

[18] John Keynes (1936, p. 129) wrote, "If the Treasury were to fill old bottles with banknotes, bury them at suitable depths in disused coalmines which are then filled up to the surface with town rubbish, and leave it to private enterprise on well-tried principles of laissez-faire to dig the notes up again (the right to do so being obtained, of course, by tendering for leases of the note-bearing territory), there need be no more unemployment and, with the help of the repercussions, the real income of the community, and its capital wealth also, would probably become a good deal greater than it actually is. It would, indeed, be more sensible to build houses and the like; but if there are political and practical difficulties in the way of this, the above would be better than nothing."
} 
Table 3. Canons of taxation.

\begin{tabular}{|c|c|c|c|}
\hline & Kautilya & \multicolumn{2}{|c|}{ Adam Smith } \\
\hline $\begin{array}{l}\text { Benefit-rule of } \\
\text { taxation }\end{array}$ & $\begin{array}{l}\text { (p. 820) "When there was no order in society and only the law of } \\
\text { the jungle prevailed, people [were unhappy and being desirous } \\
\text { of order] made Manu, the son of Vivasvat, their king; and they } \\
\text { assigned to the king one-sixth part of the grains grown by them, } \\
\text { one-tenth of other commodities and money. The king then used } \\
\text { these to safeguard the welfare of his subjects." }\end{array}$ & \multicolumn{2}{|c|}{$\begin{array}{l}\text { (Bk. V, Ch. II, p. 350) "The subjects of every state } \\
\text { ought to contribute towards the support of the } \\
\text { government, as nearly as possible, in proportion to } \\
\text { their respective abilities; That is, in proportion to } \\
\text { the revenue which they respectively enjoy under } \\
\text { the protection of the state. }\end{array}$} \\
\hline $\begin{array}{l}\text { Certainty of } \\
\text { tax }\end{array}$ & $\begin{array}{l}\text { Income tax rate was proportional and equal to one-sixth of } \\
\text { income and was fixed by the tax-payers. }\end{array}$ & \multicolumn{2}{|c|}{$\begin{array}{l}\text { "The tax which each individual is bound to pay } \\
\text { ought to be certain, not arbitrary." }\end{array}$} \\
\hline Economy & $\begin{array}{l}\text { p. 220: “A wise Chancellor is one who collects revenue so as to } \\
\text { increase income and reduce expenditure. He will take remedial } \\
\text { measures if income diminishes and expenditure increases } \\
\text { (2.6.28).” } \\
\text { (p. 284) "He who produces double the [anticipated] revenue eats } \\
\text { up the janapada [the countryside and its people, by leaving them } \\
\text { inadequate resources for survival and future production] (2.9).” } \\
\text { He (p. 181) suggested for the king, "He shall protect agriculture } \\
\text { from being harassed by (onerous) fines, taxes and demands of } \\
\text { labour (2.1).” }\end{array}$ & \multicolumn{2}{|c|}{$\begin{array}{l}\text { (p. 351) "Every tax ought to be so contrived as } \\
\text { both to take out and to keep out of the pockets of } \\
\text { the people as little as possible, over and above } \\
\text { what it brings into the public treasury of the state." }\end{array}$} \\
\hline $\begin{array}{l}\text { Convenience } \\
\text { of payment }\end{array}$ & $\begin{array}{l}\text { He (p. 253) observed, "Just as one plucks fruits from a garden as } \\
\text { they ripen, so shall a king have the revenue collected as it } \\
\text { becomes due. Just as one does not collect unripe fruits, he shall } \\
\text { avoid taking wealth that is not due because that will make the } \\
\text { people angry and spoil the very sources of revenue (5.2).” }\end{array}$ & \multicolumn{2}{|c|}{$\begin{array}{l}\text { (p. 351) "Every tax ought to be levied at the time, } \\
\text { or in the manner, in which it is most likely to be } \\
\text { convenient for the contributor to pay." }\end{array}$} \\
\hline Compliance & $\begin{array}{l}\text { The Record Keepers were responsible for collecting the taxes } \\
\text { and there were magistrates to "inspect their work and to ensure } \\
\text { proper collection of taxes" (2.35). }\end{array}$ & \multicolumn{2}{|c|}{ None } \\
\hline Market failure & Kautilya's Arthashastra & & Adam Smith's Wealth of nations \\
\hline $\begin{array}{l}\text { Monopolies and } \\
\text { monopsonies }\end{array}$ & $\begin{array}{l}\text { (p. 236) stated, "Merchants are all thieves, in effect, if not in na } \\
\text { they shall be prevented from oppressing the people (4.1)." He (p } \\
\text { added, "It is the frontier officer who promotes trade, whereas tra } \\
\text { form cartels in order to raise prices [for the goods they sell] or l } \\
\text { them [for the goods they buy]; they are profiteers making one h} \\
\text { panas on one pana or one hundred measures on one measure of } \\
\text { [grain]." }\end{array}$ & $\begin{array}{l}\text { 134) } \\
\text { lers } \\
\text { wer } \\
\text { idred }\end{array}$ & $\begin{array}{l}\text { (Book 1, Ch. XI, p. 278) wrote, "It comes } \\
\text { from an order of men, whose interest is } \\
\text { never exactly the same with that of the } \\
\text { public, who have generally an interest to } \\
\text { deceive and even to oppress the public, and } \\
\text { who accordingly have, upon many } \\
\text { occasions, both deceived and oppressed it." }\end{array}$ \\
\hline $\begin{array}{l}\text { Regulation of } \\
\text { monopolies and } \\
\text { monopsonies }\end{array}$ & $\begin{array}{l}\text { Kautilya (p. 250) recommended, "Cartelisation by artisans and } \\
\text { craftsmen with the aim of lowering quality, increasing the profi } \\
\text { obstructing the sale or purchase and by merchants conspiring to } \\
\text { with the aim of selling at a higher price (4.2)" would be dealt w } \\
\text { stiff punishments of } 1000 \text { panas for such offenses. Such a high } \\
\text { penalty indicates the perceived seriousness of the offense. He (p } \\
249.250 \text { ) recommended punishment for "adulteration", "fraud”, } \\
\text { description in selling", "showing one product and selling anothe } \\
\text { and "stealing precious metal in making new objects", etc. (4.2). }\end{array}$ & $\begin{array}{l}\text { or } \\
\text { loard } \\
\text { false }\end{array}$ & Nothing specific \\
\hline
\end{tabular}

\section{Concluding Observations}

Fairness requires that acknowledgement be given only to the thinker, who originates an idea and not to the one, who copies it and tries to claim proprietorship. Secondly, Miss Columbia, Ariadna Gutierrez was erroneously declared Miss Universe but that error was corrected in about three minutes and Miss Philippines, Pia Alonzo Wurtzbach, the rightful winner of the contest, was crowned as Miss Universe. Adam Smith was erroneously declared as the founder of economics and instead of correcting the error, concerted and coordinated efforts have been made over the last two hundred years and are still continuing to perpetuate it. Moreover, one cannot extract any butter by churning buttermilk, in this case The Wealth of Nations, unless s/he has added butter beforehand. 


\section{Acknowledgements}

I am thankful to Prof. Anthony Waterman for presenting me with a challenge to show that Kautilya's Arthashastra was a source of Adam Smith's The Wealth of Nations. I am grateful to Chandra Kant Raju and an anonymous referee for enhancing clarity and content of the paper.

\section{References}

[1] Kautilya, V. (4th Century B. C.) The Arthashastra, Edited, Rearranged, Translated and Introduced by L. N. Rangarajan. Penguin Books, 1992, New Delhi, New York.

[2] Smith, A. (1776/1976) An Inquiry into the Nature and Causes of the Wealth of Nations. Edited and with an Introduction, Notes, Marginal Summary, and Index by Edwin Cannan. The University of Chicago Press, Chicago.

[3] Prasch, R.E. (1991) The Ethics of Growth in Adam Smith’s Wealth of Nations. History of Political Economy, 23, 337351. http://dx.doi.org/10.1215/00182702-23-2-337

[4] Sihag, B.S. (2016) Comparison of Kautilya’s People-Centric Approach to Machiavelli’s King-Centric Approach, Mimeo.

[5] Dorfman, R. (1991) Review Article: Economic Development from the Beginning to Rostow. Journal of Economic Literature, XXIX, 573-591.

[6] Spengler, J.J. (1971) Indian Economic Thought. Duke University Press, Durham.

[7] Sihag, B.S. (2014) Kautilya: The True Founder of Economics. Vitasta Publications, New Delhi.

[8] Wolters, O.W. (1999) History, Culture, and Region in Southeast Asian Perspectives, Revised Edition. Cornell Southeast Asia Program, Ithaca.

[9] Strauss, L. (1987) Niccolo Machiavelli. In: Strauss, L. and Joseph, C., Eds., History of Political Philosophy, University of Chicago Press, Chicago. http://dx.doi.org/10.7208/chicago/9780226924717.001.0001

[10] Machiavelli, N. (1994) Selected Political Writings. Edited and Translated by David Wootton, Hackett Publishing, Cambridge.

[11] Barber, W.J. (1967) A History of Economic Thought. Penguin Books, Baltimore.

[12] Grampp, W.D. (2000) What Did Adam Smith Mean by the Invisible Hand? Journal of Political Economy, 108, 441465. http://dx.doi.org/10.1086/262125

[13] Rothbard, M. (1995) Economic Thought before Adam Smith: An Austrian Perspective on the History of Economic Thought. Vol. 1, Edward Elgar, Aldershot.

[14] Burnett, C. (2005) Leonard of Pisa (Fibonacci) and Arabic Arithmetic. www.muslimheritage.com

[15] Drekmeier, C. (1962) Kingship and Community in Early India. Stanford University Press, Stanford.

[16] Smith, A. (1790/1982) The Theory of Moral Sentiments. Edited by D.D. Raphael and A.L. Macfie; Liberty Fund, Indianapolis.

[17] Basham, A.L. (1959) The Wonder That Was India. Grove Press, New York.

[18] Keynes, J.M. (1936) The General Theory of Employment, Interest, and Money. Harcourt Bruce Jovanovich, New York, London. 


\section{Appendix: Transmission of Ideas from India to Europe}

How ideas get diffused? The person who has new ideas must be willing to share them and there must be a willing and capable host to receive them since these may be complementary or substitutes of his existing knowledge. Role of existing institutions and interests becomes very critical in the acceptance or rejection of new ideas. There were both direct and indirect routes for transmission of ideas from India to Europe. Roman coins at Pudukottai and at other places in southern India have been found indicating that there was brisk trade between India and Italy during the first century BCE and thereafter. In all likelihood not only there were exports of goods from India but also of ideas. Sri Lanka also served as a transfer station for transmission of ideas from India to other countries.

Kautilya's ideas were transmitted to Indonesia. A king explicitly gave credit to Kautilya's ideas for his success. [8] Wolters (p. 49) writes, "An inscription states that the 11th century Javanese king named Erlangga subverted his enemy's power "by the application of the means taught by" the author of The Arthashastra, the most famous of all Indian treaties on the policies of a successful mandala manager. The Arthashastra also contains many precepts useful for a would-be conqueror." (Wolters cites the inscription translated by B.R. Chatterji, History of Indonesia, p. 183, verse 29).

It is almost certain that Kautilya's ideas reached Europe also. Use of Indian numerals spread very quickly since they facilitated in conducting commerce and also in tracking the movements of stars and planets. For example, these numerals were transmitted to Middle-East in a matter of few decades. There was a wholesale translation of Indian books at Baghdad's House of Wisdom. Indian numerals reached Spain in 976. Vasco De Gama travelled to India in 1498, presumably, in search of exploring an alternative route to India that could allow imports of spices directly without any middle man from the Middle-East. He could have filled his boats with spices but instead he chose to take back a boat-load of books from India. Clearly, Indian books were more valuable than spices.

Most likely Machiavelli had access to Kautilya's Arthashastra. Since he discusses, although without much depth, many of the same topics, such as forming alliances, role of an adviser, role of information, types of army and specifically the delegation of unpopular task (as discussed below), as were discussed by Kautilya. He did not fully understand the Arthashastra, was short of time since he was desperate to find work or tried to modify it to make it look original. As noted by [9] Leo Strauss (1987), Machiavelli was very good in imitation. Leo Strauss (p. 316) remarks, “Almost all those sayings have been borrowed by Machiavelli from Diogenes Laertius' Lives of the Famous Philosophers. Machiavelli changes the sayings in some cases in order to make them

Table A1. Kautilya and Machiavelli on delegation.

\begin{tabular}{|c|c|}
\hline Kautilya (Arthashastra, $4^{\text {th }}$ century BCE) & 10] Machiavelli (Prince, 513 CE) \\
\hline $\begin{array}{l}\text { ON Vices } \\
\text { Page 137: “Anger makes one the object of hatred, creates enemies and brings } \\
\text { suffering on oneself. Excessive greed and lust bring about humiliation, loss of } \\
\text { wealth and association with undesirable persons like thieves, gamblers, hunters, } \\
\text { singers and musicians. [While both have had bad consequences,] being hated is } \\
\text { worse than humiliation; whereas one humiliated is held in thrall by his own } \\
\text { people and by enemies, a hated one is destroyed.” } \\
\text { Anticipating and Avoiding Discontent } \\
\text { Page 158: "Spies in the guise of ascetics shall find out who among the } \\
\text { following are happy and who discontented: } \\
\text { Those dependent on the King for grains, cattle or money; those who help the } \\
\text { King in prosperity and adversity; those who [help to] restrain an angry relative } \\
\text { or region and those who repel enemies and forest chiefs. } \\
\text { The contented shall be appreciated by giving them additional honors and } \\
\text { wealth. } \\
\text { In order to make the discontented happy, conciliation shall be the method used. } \\
\text { If [conciliation fails and] they continue to be unhappy, they shall be used to } \\
\text { collect taxes and fines so that they may incur the wrath of the public. When the } \\
\text { people come to hate them, they shall be eliminated either by inciting a popular } \\
\text { revolt against them or by secret punishment. Alternatively, they may be sent to } \\
\text { work in mines and factories while keeping their wives and sons under close } \\
\text { security in order to prevent them from being used by enemies.” }\end{array}$ & $\begin{array}{l}\text { Ch. 19, page 58: "For whoever set up the government } \\
\text { of that country understood the powerful are ambitious } \\
\text { and insolvent, and judged it necessary they should be } \\
\text { bridled so they could be controlled, but on the other } \\
\text { hand he recognized the hatred most people have for } \\
\text { the powerful, whom they have reason to fear, and the } \\
\text { consequent need to reassure and protect the great. So } \\
\text { he did not this to be the responsibility of the king, in } \\
\text { order to avoid his alienating the powerful by favoring } \\
\text { the people or alienating the people by favoring the } \\
\text { powerful, and he established an independent tribunal, } \\
\text { whose task it is, without incurring blame for the king, } \\
\text { to crush the powerful and defend the weak. This } \\
\text { arrangement is as intelligent and prudent as could be, } \\
\text { and makes a substantial contribution to the security of } \\
\text { the king and the stability of the kingdom. This } \\
\text { institution enables us to recognize a significant } \\
\text { general principle: Rulers should delegate } \\
\text { responsibility for unpopular actions, while taking } \\
\text { personal responsibility for those that will win favor. } \\
\text { And once again I conclude a ruler should treat the } \\
\text { powerful with respect, but at all costs he should avoid } \\
\text { being hated by the people." }\end{array}$ \\
\hline
\end{tabular}


suitable to Castruccio. In Diogenes, an ancient philosopher is recorded as having said that he would wish to die like Socrates; Machiavelli makes this Castruccio’s saying, yet he would wish to die like Caesar.”

Machiavelli imitates Kautilya in recommending that a king should delegate an unpopular task to someone else so that the king does not become object of hatred. Table A1 presents their views on delegation.

This similarity of views on delegation leaves little doubt that Machiavelli had access to The Arthashastra. But To Machiavelli's credit, he (1513, Ch. 6, p. 18) wrote, "But you cannot exactly in the footsteps of those who have gone before, nor is it easy to match the skill [virtu] of those you have chosen to imitate.” Who were the "many authors" referred to by Machiavelli (p. 48)? Possibly Kautilya was one of them. Kautilya had emphasized the critical role of the ethical values in bringing prosperity.

Similarly, Indian methods of navigation were also transmitted very quickly to Europe. There is new research showing the transmission of calculus from India to Europe. Interestingly, even Indian cows have reached Texas, USA through Africa-Europe-Caribbean-Mexico. Given all these facts, it is unthinkable that other Indian thought including Kautilya's Arthashastra had not reached Europe. 